\title{
Exchange Transfusion: Indication and Adverse Effect
}

\author{
SURAIYA BEGUM ${ }^{1}$, MD. ABDUL BAKI ${ }^{2}$, GOPEN KUNDU ${ }^{1}$, IMNUL ISLAM ${ }^{1}$, MANIK KUMAR TALUKDAR ${ }^{1}$, \\ KANIZ FATEMA ${ }^{1}$
}

\begin{abstract}
:
Objective: To determine the indication and complications of exchange transfusion (ET) performed for neonatal hyperbilirubinaemia.

Methods: The medical records of infants $<28$ days old who required exchange transfusion (ET) due to neonatal jaundice in Special Care Baby Unit (SCABU), BIRDEM hospital from January 2009 to April 2010 were retrospectively reviewed.

Results: Exchange transfusion was performed in 30 neonates during the study period. Indications of exchange transfusion were $A B O$ incompatibility (30.0\%), Rh incompatibility (13.3\%), septicaemia (6.6\%) and in majority causes, were unidentified (50\%). Most common complication were thrombocytopenia (33.3\%) hyperkalaemia (20\%), hypocalcaemia (16.7\%)

Conclusion: Indication of ET was unidentified in majority cases and among identified cases most common causes was ABO incompatibility. Adverse events were common after exchange transfusion.
\end{abstract}

\section{Introduction}

Approximately $60 \%$ of healthy term neonates have clinical jaundice in the first week after birth ${ }^{1-4}$. About $0.02-0.16 \%$ of these infants develop extreme hyperbilirubinemia $\left(e^{\prime \prime} 428 \mathrm{mmol} / \mathrm{L}\right)^{1,5}$. Treatment is usually given for the prevention of bilirubin encephalopathy ${ }^{4}$. When the bilirubin is rising continuously, instead of declining in spite of phototherapy, to the level that kernicterus is considered a threat, then exchange transfusion (ET) is considered. Although ET is considered to be a safe procedure, it is not risk free, and mortality rates vary from 0.5 to $3.3 \%{ }^{6-9}$. The level of bilirubin concentration at which ET should be indicated remains the subject of disagreement, since the incidence of bilirubin encephalopathy also depends on other variables such as gestational age, the presence or absence of haemolysis and the newborn's clinical status. Current recommendations for performing ET are based on balance between the risks of encephalopathy and the adverse events related to the procedure ${ }^{10}$. This study was undertaken with the objectives of determination of the indication of exchange transfusion and also to

1. Assistant Professor, Department of Paediatrics, Bangabandhu Sheikh Mujib Medical University, Dhaka 2. Registrar, Department of Paediatrics, BIRDEM Hospital, Dhaka Correspondence: Dr. Suraiya Begum evaluate the morbidity and mortality associated with the procedure.

\section{Materials and methods}

The medical records of infants $<28$ days old who required $E T$ due to neonatal jaundice in Special Care Baby Unit (SCABU), BIRDEM hospital from January 2009 to April 2010 were retrospectively reviewed. ET procedures were performed by the medical team of the unit. Infants' heart rate and oxygen saturation were monitored during the procedure. The umbilical vein was the only access employed for the procedure and the volume of blood used in the exchange corresponded to twice the patient's blood volume. In all cases, whole blood was used for the procedure within 12 hours after collection. All patients were given to phototherapy before and after the procedure. Serum bilirubin , complete hemogram including reticulocyte count, blood grouping ( $\mathrm{ABO}$ and $\mathrm{Rh}$ ) for mother and baby and direct Coomb's test report were collected for all babies. The morbidity and mortality caused by each ET which occurred within 3 days of the procedure was defined as complications. All episodes of complication were recorded. Statistical analysis was carried out using SPSS (version 12.0). 


\section{Results}

Exchange transfusion was done in 30 neonates during the study period. Among them $13(43.33 \%)$ were male and $17(56.67 \%)$ were female; $63 \%$ were inborn and $37 \%$ were outborn. Mean gestational age of neonates was $33.33 \pm 3.67$ wks and mean birth weight was $1725 \pm 400 \mathrm{gm}$. Twenty two (73.34\%) baby were preterm and $8(26.66 \%)$ baby were term (Table-I). In this study $46.7 \%$ were infant of diabetic mother, $10 \%$ neonate had respiratory distress syndrome and $6.66 \%$ had birth asphyxia (Table-II).

Table-I

Clinical-pathological characteristics of neonate $(n=30)$

\begin{tabular}{|c|c|c|}
\hline \multicolumn{3}{|c|}{ Place of delivery } \\
\hline & Inborn & $19(63.33 \%)$ \\
\hline & Outborn & $11(36.67 \%)$ \\
\hline \multirow[t]{2}{*}{ Sex } & Male & $13(43.33 \%)$ \\
\hline & Female & $17(56.67 \%)$ \\
\hline \multicolumn{3}{|c|}{ Gestational period } \\
\hline & Term & $8(26.66 \%)$ \\
\hline & Preterm & $22(73.34 \%)$ \\
\hline & Mean $\pm S D$ & $33.33 \pm 3.67$ weeks \\
\hline \multicolumn{3}{|c|}{ Birth weight } \\
\hline & Mean $\pm S D$ & $1725 \pm 400 \mathrm{gms}$ \\
\hline \multicolumn{3}{|c|}{ Pre exchange $\mathrm{S}$. bilirubin $\mathrm{mg} / \mathrm{dl}$} \\
\hline & Maximum & $31.6 \mathrm{mg} / \mathrm{dL}$ \\
\hline & Minimum & $11.6 \mathrm{mg} / \mathrm{dl}$ \\
\hline & Mean & $21.37( \pm 5.10) \mathrm{mg} / \mathrm{dl}$ \\
\hline \multicolumn{3}{|c|}{ Post exchange S. bilirubin mg/dl } \\
\hline & Maximum & $17.3 \mathrm{mg} / \mathrm{dl}$ \\
\hline & Minimum & $3.8 \mathrm{mg} / \mathrm{dl}$ \\
\hline & Mean & $8.46 \pm 2.94 \mathrm{mg} / \mathrm{dl}$ \\
\hline \multicolumn{3}{|c|}{ Day of Exchange Transfusion } \\
\hline & Mean $\pm S D$ & $5.2 \pm 1.62$ day \\
\hline \multicolumn{3}{|c|}{ Direct coomb's test } \\
\hline & Positive & $5(38.46 \%)$ \\
\hline & $A B O+v e$ & $3(33 \%)$ \\
\hline & Rh+ve & $2(50 \%)$ \\
\hline
\end{tabular}

Table-II

Contributing factors for Exchange Transfusion

\begin{tabular}{lc}
\hline Contributing factors & No (\%) \\
\hline Preterm & $22(73.34 \%)$ \\
Infant of diabetic mother & $14(46.7 \%)$ \\
Respiratory distress syndrome & $3(10 \%)$ \\
Birth asphyxia & $2(6.66 \%)$ \\
\hline
\end{tabular}

Mean serum bilirubin was $21.37( \pm 5.10) \mathrm{mg} / \mathrm{dl}$ at the time of exchange transfusion. Fig.-1. Shows the indications for which neonates needed exchange transfusion. Among the 30 cases, no causes were unidentified in $50 \%$ of the neonates, $A B O$ incompatibility was found in $30.0 \%$, Rh incompatibility in $13.3 \%$ and septicemia was found in $6.6 \%$ cases. Multiple exchange transfusions were required in 10\% neonates. Post exchange mean serum bilirubin was $8.46( \pm 2.94) \mathrm{mg} / \mathrm{dl}$ and mean day of exchange transfusion was $5.2 \pm 1.62$ day.

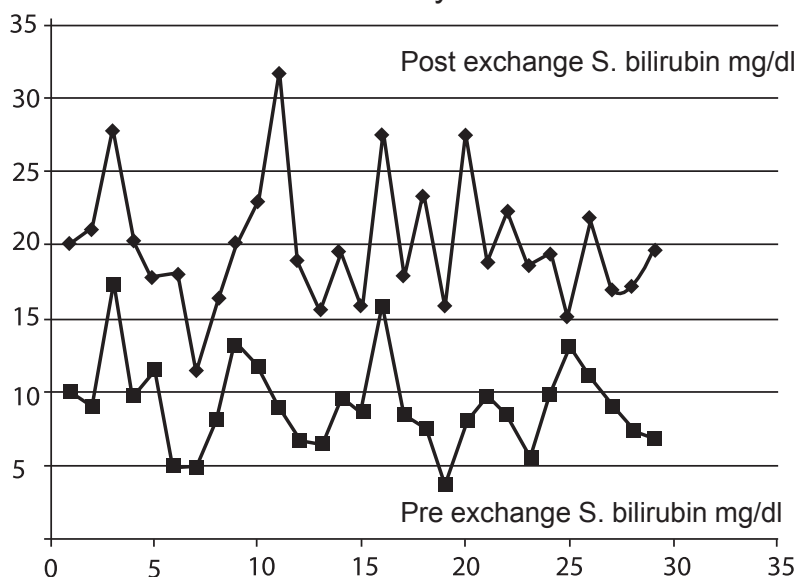

Fig.-1: S. bilirubin $\mathrm{mg} / \mathrm{dl}(n=30)$

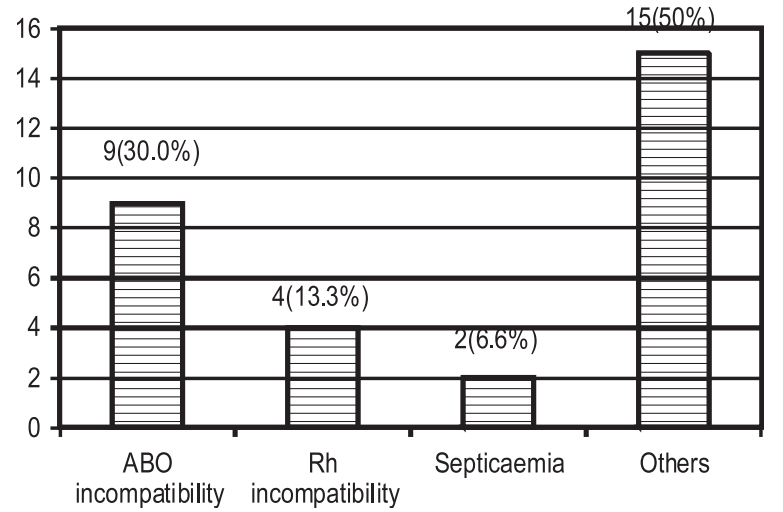

Fig.-2: Indication of Exchange Transfusion $(n=30)$

Table -III

Complications of Exchange Transfusion

\begin{tabular}{lcc}
\hline Complications & $\mathrm{n}$ & $\%$ \\
\hline Trombocytopenia & 10 & 33.3 \\
Hyperkalaemia & 06 & 20.0 \\
Hypocalcaemia & 05 & 16.7 \\
Hypoglycaemia & 04 & 13.3 \\
Hyponatraemia & 04 & 13.3 \\
Septicaemia & 01 & 3.3 \\
Death & 01 & 3.3 \\
\hline
\end{tabular}


During and immediately after exchange transfusion $60.0 \%$ baby developed complications. Most common complications were thrombocytopenia (33.3\%), hyperkalaemia $(20.0 \%)$, hypocalcaemia $(16.7 \%)$, hypoglycaemia (13.3\%), hyponatraemia (13.3\%) and septicaemia (3.3\%). One (3.3\%) baby died after exchange transfusion due to extreme prematurity (26wks) and incredibly low birth weight $(650 \mathrm{mg})$, and developed septicaemia and electrolyte imbalance following ET.

\section{Discussion}

Exchange blood transfusion remains the gold standard for effective treatment of neonatal hyperbilirubinaemia. Although exchange transfusion rate was progressively declining over the years, it is still required in up to $7 \%$ of neonates admitted to nurseries ${ }^{11}$. This reduction in the number of exchange transfusion may be due to the development of anti-Rh globin for Rh-negative mothers and the widespread use of phototherapy for neonatal jaundice ${ }^{12,13}$. In this study, causes of exchange transfusion were unidentified in 15 (50\%) cases. Infant of diabetic mother $(46.7 \%)$, prematurity $(73.3 \%)$, respiratory distress syndrome $(8.57 \%)$ and birth asphyxia $(5.7 \%)$ were risk factors for hyperbilirubinaemia needed ET in this group. Narag A et al analyzed 501 cases of neonatal jaundice and they found that in $52 \%$ cases no cause for exchange transfusion was identified ${ }^{14}$. Exchange transfusion was done due to $A B O$ incompatibility in $9(30 \%)$ cases, which was similar to the findings in some other series. Dikshit and Sanpavat reported that ABO haemolytic disease of newborns was the most common cause of ET in neonates $(35.9 \% \text { and } 21.3 \% \text {, respectively })^{15}$, 16. Multiple exchange transfusion was required in $10 \%$ of our neonates. This is similar to findings of AbuEkteish et al ${ }^{17}$, but is lower than Dikshit SK study ${ }^{15}$.

Despite improvement in neonatal intensive care in the past two decades, exchange transfusion remains a high-risk procedure. One (3.3\%) of the 30 patients in this study died of complications probably attributable to exchange transfusion. This neonate was extremely premature (26wks) and incredibly low birth weight $(650 \mathrm{mg})$, and developed septicaemia and electrolyte imbalance following ET.

Panagopoulos et al in Greece examined 606 exchanges performed on 502 neonates between 1962 to 1966 and reported a mortality rate of $0.66 \%$ per patient and $0.79 \%$ per procedure; Keenan et al reported a mortality rate of $0.5 \%$; but Chima et al reported no serious adverse event or death in 22 infants who underwent 26 ET between 1990 and 1998 ${ }^{18-20}$.

Eighteen baby (60\%) developed complications. Most common complications were thrombocytopenia (33.3\%), hyperkalaemia (20.0\%) and hypocalcaemia (16.7\%). Badiee $Z$ in his study done in Iran found similar results. In that study common complications of ET was hypocalcaemia $(29.0 \%)$ and thrombocytopenia $(44 \%)^{21}$.

In conclusion, though sample size was small, this report indicates that $A B O$ incompatibility was the commonest identified cause of exchange transfusion. Adverse events remain common after exchange transfusion. Most of the complications were transient and improved with treatment. Mortality rate was low in this study. So it is still a good modality of treatment for severe neonatal jaundice.

\section{References:}

1. Bhutani VK, Johnson LH, Keren R. Diagnosis and management of hyperbilirubinemia in the term neonate: for a safer first week. Pediatr Clin North Am 2004; 51(4): 843-61.

2. Kapplan M, Hammerman C. Understanding and preventing severe neonatal hyperbilirubinemia: is bilirubin neurotoxicity really a concern in the developed world? Clin Perinatol 2004; 31(3): 555-7.

3. Porter ML, Dennis BL. Hyperbilirubinemia in the term newborn. Am Fam Physician 2002; 65(4): 599-606.

4. Smitherman H, Stark AR, Bhutani VK. Early recognition of neonatal hyperbilirubinemia and its emergent management. Semin Fetal Neonatal Med 2006; 11(3): 214-24.

5. Ebbesen F, Andersson C, Verder H, Grytter C, Pedersen- Bjergaard L, Petersen JR, et al. Extreme hyperbilirubinaemia in term and nearterm infants in Denmark. Acta Paediatr 2005; 94(1): 59-64.

6. Bowman J. The management of hemolytic disease in the fetus and newborn. Semin Perinatol 1997; 21(1): 39-44.

7. Philip AG. The rise and fall of exchange transfusion. NeoReviews 2003; 4: 169-74.

8. Ip S, Chung M, Kulig J, O'Brien R, Sege R, Glicken $S$ et al. An evidence-based review of important issues concerning neonatal hyperbilirubinemia. Pediatrics 2004; 114(1): 130-53. 
9. Boggs TR Jr, Westphal MC Jr. Mortality of exchange transfusion. Pediatrics 1960; 26: 74555.

10. Jackson JC. Adverse events associated with exchange transfusion in healthy and ill newborns. Pediatrics 1997; 99: 7.

11. Funato M, Tamai $H$, Shimada $S$. Trends in neonatal exchange transfusions at Yodogawa Christian Hospital. Acta Pediatr Jpn 1997; 39(3):305-8.

12. Lucey JF. Neonatal jaundice and phototherapy. Pediatr Clin North Am 1972; 19(4): 827-39.

13. Woodrow JC. Effectiveness of Rh prophylaxis. Haematologica (Budap) 1974; 8:281-90.

14. Anil Narang, Geeta Gathwala, Praveen Kumar. Neonatal Jaundice: An Analysis of 551 Cases. Indian pediatrics 1997; 5: 429-32.

15. Dikshit SK, Gupta PK. Exchange transfusion in neonatal hyper -bilirubinemia. Indian Pediatr 1989; 26(11):1139-45.
16. Sanpavat S. Exchange transfusion and its morbidity in ten-year period at King Chulalongkorn Hospital. J Med Assoc Thai 2005; 88: 588-92.

17. Abu-Ekteish F, Daoud A, Rimawi H, Kakish K, Abu-Heija A. Neonatal exchange transfusion: a Jordanian experience. Ann Trop Paediatr 2000; 20: 57-60.

18. Panagopoulos G, Valaes T, Doxiadis SA. Morbidity and mortality related to exchange transfusions. J Pediatr 1969; 74: 247-54.

19. Keenan WJ, Novak KK, Sutherland JM, Bryla DA, Fetterly KL. Morbidity and mortality associated with exchange transfusion. Pediatrics 1985; 75: 417-21.

20. Chima RS, Johnson LH, Bhutani VK. Evaluation of adverse events due to exchange transfusion in term and near-term newborns. Pediatr Res 2001; 49: 32-4.

21. Badiee $Z$ Exchange transfusion in neonatal hyperbilirubinaemia: experience in Isfahan, Iran. Singapore Med J 2007; 48(5): 421-3. 